\title{
Influence of civilisational factors on the development of Vietnam's law in the colonial period
}

\author{
Vera Borisovna Romanovskaya ${ }^{11}$, Nikolay Vladimirovich Ostroumov $^{2}$, Maksim Nikolaevich \\ Fomichev $^{3}$, Faridun Zavurbekovich Zavurbekov ${ }^{1}$, and Ekaterina Andreevna Esaeva $^{1}$ \\ ${ }^{1}$ Lobachevsky State University of Nizhny Novgorod, Faculty of Law, Department of Theory and \\ History of the State and Law, Nizhny Novgorod, Russia \\ ${ }^{2}$ Lobachevsky State University of Nizhny Novgorod, Faculty of Law, Department of Civil Law and \\ Procedure, Nizhny Novgorod, Russia \\ ${ }^{3}$ Volga State University of Water Transport, Institute of Economics, Management and Law, \\ Department of Civil Law Disciplines, Nizhny Novgorod, Russia
}

\begin{abstract}
Purpose of the research is to study the influence of the traditional norms and customs on the formation of the Vietnamese law in the pre-colonial period, to show their influence on the legal consciousness of its residents during the French protectorate, to substantiate the fact that this influence prevented the French colonial administration from establishing its rules without regard for the local specifics. The basic approach to studying the law of Vietnam in the colonial period is the civilisational approach which is based on the idea of correlation of law and economy, with a predominant consideration of spiritual, moral and cultural factors of the social development. The general methodological basis is presented by the dialectical method which enabled the authors to study the object of research in development, to establish the relevant cause-and-effect relations. The result of the work is the conclusion that one of the main elements of the Vietnamese culture, that had a noticeable impact on legal regulations, is the cult of ancestors. Folk beliefs are an integral part of the national history, culture, law, worldview of the Vietnamese; they have much influenced the formation of civil legislation of the colonial and present-day Vietnam. The novelty of the work is determined by the fact that the influence of spiritual and cultural factors on the attempts to introduce the new laws on the territory of Tonquin (North Vietnam) is considered for the first time.
\end{abstract}

Keywords: Dainam, Hùng Vương kings, Lê Code, ancestor cult

\section{Introduction}

Law, from the point of view, prevailing in the Russian science of the Soviet period, was considered a derivative of the state, i.e. a product of governmental activity. The civilisational approach, which has finally achieved due priority in the system of scientific

\footnotetext{
${ }^{1}$ Corresponding author: Vera_borisovna@mail.ru
} 
approaches within the modern Russian theory of state and law, defines law as a result of civilisational development including changes in the socio-cultural environment, people's spiritual life, culture and traditions. Among the numerous instances of confirmation of this thesis, the history of the Vietnamese law of the colonial period and of our time is a demonstrative example illustrating the influence of ancient moral norms and folk traditions on the attempts of foreign reformers to change the legal norms of this country. According to Florence Nguyen-Rou, an ethnologist and lawyer, ancestor worship is "a factor of social and family cohesion" [1], which was confirmed in the legal customs of the people of Vietnam (Dainam).

\section{$2 \quad$ Methods}

The study of Vietnamese traditional beliefs and legal norms requires a certain delicacy since the Asian legal consciousness and culture have specific features. The basic approach to the study of the law of Vietnam in the colonial period is the civilisational approach which is based on the idea of correlation of law and economy, with a predominant consideration of the spiritual, moral and cultural factors of the social development. To explore the highlighted subject, the authors used modern general scientific methods involving cognition of social processes: dialectical method, formal/logical (analysis, synthesis) and special methods of historical research (historical/chronological, historical/descriptive), as well as the method of systemic analysis of statutory legal sources. Much attention was paid to the research vocabulary as it was formulated in the Vietnamese language.

\section{Discussion}

The study of modern law requires comprehension of the historical processes and phenomena that contributed to the changes in the social, economic, political and spiritual spheres. An important factor of the spiritual life of the Vietnamese is the cult of ancestors as an element of the social and traditional heritage. At the present stage, the influence of the ancestor cult on the formation and development of Vietnamese legislation in different periods remains poorly explored, especially in the Russian legal literature. The ancestor cult and other related cults in Vietnam largely determine the worldview of the Vietnamese and "represent one of the elements reflecting the Vietnamese national identity" [2]. "The custom of worshiping the ancestors stems from the belief that the soul of the deceased still exists in this world and affects the lives of its descendants" [2]. According to the Confucian ideology that prevailed in Vietnam in the period from the 13th to the 18th century (Dainam), "ancestor worship is a form of filial piety" [2]. The cult of ancestors formed in ancient times in Vietnam is closely intertwined with other forms of religious beliefs. They get incorporated into life, becoming people's morality, and are reflected in the Vietnamese principle "when you drink water remember of the source". Fan Ngọc, a renowned Vietnamese scholar and translator of classical literature, notes that the common practice of worshiping spirits of the deceased brings people together [2].

In the primitive society, under matriarchy, totemism embodied the forces of nature known as the totem of the clan. With the transition to patriarchy, the worship of the nature-forces totem was transformed into the worship of the male-ancestors totem [3]. In the course of historical development, the concept of the ancestor has undergone certain changes. The ancestor concept extended, developing from the constrained genealogy tradition into the notion covering the society and the state. Therefore, the ancestor cult in Vietnam exists, as it were, on three levels: the family, the community and the state. Owing 
to the ancestor cult, the foundations of the patriarchal family continued to be preserved at the colonial period, without changing under the pressure of the rapidly developing economy. At the state level, the cult of ancestors is exercised through the worship of national heroes and symbols: the dragon Lạc Long Quân, the fairy Âu Cơ (in mythology, the forebears of the Vietnamese nation), the Hùng Vương Kings (the legendary founders of Vietnam's statehood). By the decree of Hồ Chí Minh, Chair of the Government of the Democratic Republic of Vietnam, No. 22-SL dated February 18, 1946, the Day of Remembrance of the Hùng Vương Kings was declared a national holiday [4]. In December 2012, UNESCO [5] recognised the worship of the Hùng Vương kings to be a cultural heritage [6]. In 2019, the National Assembly of the Socialist Republic of Vietnam approved an amendment and a supplement to Article 112 of the Labour Law, that allowed employees to take a paid leave on the Hùng Vương Kings Remembrance Day [7]. The influence of the traditional cults on the most important regulatory acts of the state is noticeable even in modern Vietnam. The cult of ancestors is inherently rooted in the consciousness of the Vietnamese regardless of their location. In particular, many pagodas in France include ancestor worship sites. "Buddhism is gradually striving for the majority of believers to absorb and assimilate ancestor worship" [8] .

Jérôme Gidoin a modern French scholar, writes that ancestor worship forms, at the family and community levels, from ancient times until now, vary in different parts of Vietnam [8] (this concerns the place of the altar in the house, the objects placed on the altar, etc.). Every event in family life involves the ancestors [1]. Léopold Michel Cadière, a French missionary and researcher of beliefs and practices of Vietnam, points out that the rituals practiced before the Vietnamese marriage and during the wedding as such can be regarded as an act of filial piety, aimed to preserve the lineage and the continuity of generations [9]. The famous 19th-century French geographer Élisée Reclus writes: "Every village in Tonquin has its patron spirit, every spirit has its own temple, and the religious rituals are different everywhere" [10]. The ancestor cult remains one of the basic elements of the culture of the Vietnamese society, having withstood all external circumstances. The Jesuits' missionary activity, the French colonisation, the globalisation of economy failed to belittle the importance of the ancestor cult for the Vietnamese people. Louis de Chevrey, a missionary, described how the local ancestor cult influenced the church (Christian) service: "They set up a large table, placed a small icon and two burning candles at one end of it. After that, men proceeded to approaching it with low, rhythmic courtesy bows" [11].

In 1927, the Supreme Governor of Tonquin issued a decree on setting up an ad hoc committee for the development of a new Tonquin Civil Code. The mission of the committee included questioning of the local population on the issues of marriage and family traditions and land use, as well as the development of relevant chapters of the code. One of the results of the committee's work was the inclusion of a title dedicated to the "cult heritage" in the Tonquin Civil Code of 1931. Title XII regulated the legal property-related issues and distinguished special lands and objects: Huong-hoa ${ }^{2}, K_{y}-$ diên $^{3}$ and Hàu-diên ${ }^{4}$. These norms are a reflection of the traditional beliefs of the Vietnamese. The French administration understood the importance of these traditions.

\footnotetext{
${ }^{2}$ Huong-hoa is a part of movable or immovable property intended to maintain the worship of paternal ancestors. It comprises any property that can yield income intended to maintain deification regardless of the religion of the deceased.

${ }^{3}$ Ky-diên represents inherited real estate established to celebrate funerals and ancestor worship.

${ }^{4}$ Hàu-diên represents immovable property transferred to a chüa or any other religious institution for the worship of its founder or one of its paternal or maternal parents on a specified date.
} 
Huong-hoa was instituted by a special notarial deed or by will [12]. The deed of institution was to be signed by its founder and the paternal family members [13]. People with no family were allowed to establish Huong-hoa as well. Article 398 of the Tonquin Civil Code of 1931 limited the scope of Huong-hoa to 1/5 of the total value of the founder's estate. Ky-diên was registered in the same formal way as Huong-hoa [14]. In the event of the disappearance of a family, the property was passed into state ownership [15].

Hàu-diên was established by a special deed. The deed was signed by the founder, on the one part, and a representative of the religious organisation (the beneficiary), on the other part. The deed specified the location and the area of the estate transferred to the beneficiary, as well as the duties of worship for each religious holiday [16]. Hàu-diên was not allowed to be gifted, and in case of delinquency in duties, the founder or his descendants could demand restitution.

The cult heritage property was limited in circulation. According to the general rule, Huong-hoa property was inalienable for six generations, but it was possible, in virtue of article 431 , to exchange or sell a part of it by decision of a family meeting - if the family did not have due funds to repair this property. Ky-diên could also be sold or exchanged for a good reason, if decided so by the family meeting [17]. The norms regarding traditional cults were enshrined in the legislation. However, the 1931 Code introduced a new regime for cult-heritage-land registration, involving scriptory formalisation of documents [18] with a village chief, which contradicted to the custom of the verbal institution of cult lands.

\section{Conclusion}

The ancestor cult, which originated in ancient times, does not lose its relevance at present, continuing to influence the law of modern Vietnam. In conjunction with the cult of the nation's patron spirit, the ancestor cult serves as one of the main elements of the legitimacy of the political elite, as a means for maintaining socio-political stability. The cult of ancestors, forming the mentality of the nation, had a significant impact on the Vietnamese reality, realigning the innovations introduced by missionaries and French colonists. The influence of traditional beliefs is specifically traced in the colonial legislation. By introducing the title on cult heritage in Tonquin Civil Code, the French administration made a trade-off between the economic benefits of France and the spiritual needs of the Vietnamese population. It should be noted that the code included the norms for compulsory registration of religious property, to the benefit of the colonial order.

The contemporary legislation of Vietnam also retains the influence of traditional cults. This is proved by Article 24 of the Constitution of the Socialist Republic of Vietnam of 2013 [19] - which guarantees freedom of worship - and the amendments to the Labour Code of 2019.

\section{References}

1. F. Nguyen-Rouault, Hommes \& Migrations Année, 1232/26, 26-33, 2001

2. P. Ngọc, Bản sắc văn hóa Việt Nam. Văn hóa thông tin. Tr. 350. (1998)

3. L. T. Son, Một Số Đặc Trưng Cơ Bản Của Tín Ngưỡng Thờ Cúng Tổ Tiên Của Cộng Đồng Người Việt Ở Nam Bộ

4. S. Lệnh, Của chủ tịch nước SỐ 22/SL ngày 18 tháng 2 năm 1946 Chủ tịch chính phủ lâm thời việt nam dân chủ cộng hoà (2021). Accessed on: February 3, 2021. [Online]. Available: 
https://thuvienphapluat.vn/van-ban/Lao-dong-Tien-luong/Sac-lenh-22-SL-an-dinh-nga y-tet-ky-niem-lich-su-le-ton-giao-35954.aspx

5. Decision of the Intergovernmental Committee: 7.COM 11.36. Accessed on: February 3, 2021. [Online]. Available: https://ich.unesco.org/en/decisions/7.COM/11.36

6. U. Linh, Lịch sử, ý nghĩa ngày Giỗ Tổ Hùng Vương, baodautu.vn (2018). Accessed on: February 3, 2021. [Online]. Available:

https://baodautu.vn/lich-su-y-nghia-ngay-gio-to-hung-vuong-103-am-lich-d19278.html \#: :text=L\%E1\%BB\%8Bch\%20s\%E1\%BB\%AD\%2C\%20\%C3\%BD\%20ngh\%C4\%A 9a\%20ng\%C3\%A0y,V\%C6\%B0\%C6\%A1ng\%2010\%2F3\%20\%C3\%82m\%201\%E1\% BB $\% 8$ Bch\&text=L\%E1\%BB $\% 85 \% 20 \mathrm{~h} \% \mathrm{E} 1 \% \mathrm{BB} \% 99 \mathrm{i} \% 20 \% \mathrm{C} 4 \% 90 \% \mathrm{E} 1 \% \mathrm{BB} \% 81 \mathrm{n}$ $\% 20 \mathrm{H} \% \mathrm{C} 3 \%$ B9ng\%20c\%C3\%B2n, \%C4\%91\%E1\%BA\%A7u $\% 20$ ti $\%$ C3\%AAn $\% 20$ c $\%$ E1\%BB $\%$ A7a $\% 20 \mathrm{~d} \% \mathrm{C} 3 \%$ A2n $\% 20 t \%$ E1\%BB $\% 99$ c.\&text $=$ C $\%$ C3\%A2u $\% 20$ ca $\% 20$ dao $\% 20 \%$ C4\% $\% 1 \%$ E1\%BA\%ADm\%20\%C4\%91\%C3\%A0,n\%C3\%A0y\%20sang\%20 th $\%$ E $1 \%$ BA $\%$ BF\% $20 \mathrm{~h} \%$ E1\%BB $\% 87 \% 20 \mathrm{kh} \% \mathrm{C} 3 \% \mathrm{~A} 1 \mathrm{c}$

7. Bộ luật số: 45/2019/QH14 ngày 20 tháng 11 năm 2019 Lao Động. Accessed on: February 3, 2021. [Online]. Available:

https://thuvienphapluat.vn/van-ban/Lao-dong-Tien-luong/Bo-Luat-lao-dong-2019-3336 70.aspx

8. Gidoin J. Un culte des ancêtres revisité ? Les pratiques d'hommage aux défunts des Vietnamiens réinterprétées à partir du bouddhisme en région parisienne. Accessed on: February 3, 2021. [Online]. Available: http://www.cargo.canthel.fr/wp-content/uploads/2016/04/GidoinCargo3.pdf

9. L. Cadière, Croyances et pratiques religieuses des Vietnamiens, tome 1, p. 49-50 (École Française d'Extrême-Orient, Paris, 1992)

10. E. Reclus, The universal geography: earth and its inhabitants, vol. 8, p. 840. - India and Indochina (St. Petersburg, 1899). Accessed on: February 3, 2021. [Online]. Available: http://kolanord.ru/html_public/novye/RekleE_Zemlya-i-lyudi_T8-9_1899/430/

11. O.V. Novakova, South-East Asia: topical problems of development, 24 (2014). Accessed on: February 3, 2021. [Online]. Available:

https://cyberleninka.ru/article/n/pervye-vietnamskie-svyaschenniki-v-tonkine-i-kohinhi ne-1660-e-gg-konets-Xvii-v

12. Code civil à l'usage des juridictions indigènes du Tonkin, Hanoi, art. 395 (1931)

13. Code civil à l'usage des juridictions indigènes du Tonkin, Hanoi, art. 396 (1931)

14. Code civil à l'usage des juridictions indigènes du Tonkin, Hanoi, art. 438 (1931)

15. Code civil à l'usage des juridictions indigènes du Tonkin, Hanoi, art. 442 (1931)

16. Code civil à l'usage des juridictions indigènes du Tonkin, Hanoi, art. 445 (1931)

17. Code civil à l'usage des juridictions indigènes du Tonkin, Hanoi, art. 440 (1931)

18. Code civil à l'usage des juridictions indigènes du Tonkin, Hanoi, art. 395 (1931)

19. Hiến pháp nước Cộng hòa xã hội chủ nghĩa Việt Nam năm ngày 28 tháng 11 năm 2013. Accessed on: February 3, 2021. [Online]. Available: https://thuvienphapluat.vn/van-ban/Bo-may-hanh-chinh/Hien-phap-nam-2013-215627. aspx 